\title{
Factors Influencing Green Practices Adoption and Infusion by Manufacturing Companies in Ogun State, Nigeria
}

\author{
Mayowa Oludele Solaja ${ }^{1 *}$, Bright Obatunde Adetola ${ }^{1}$, Emmanuel Emeka Okafor $^{2}$ \\ ${ }^{1}$ Department of Sociology, Olabisi Onabanjo University, Ago-Iwoye, Nigeria \\ ${ }^{2}$ Department of Sociology, University of Ibadan, Ibadan, Nigeria \\ *Corresponding author email: postgraduatescholar@gmail.com
}

\begin{tabular}{llll} 
Article history & & \\
\hline Received & Received in revised form & Accepted & Available online \\
10 February 2020 & 30 March 2020 & 31 March 2020 & 31 March 2020 \\
\hline
\end{tabular}

\begin{abstract}
This study examined factors influencing the adoption and infusion of green practices by manufacturing companies in Ogun State, Nigeria. The study adopted a cross-sectional and descriptive survey research design. Area-based technique in which multi-stage sampling technique was used to select 321 employees of medium and large-sca2le manufacturing firms in Ogun State, Nigeria. A semi-structured questionnaire was used for data collection. The data were analysed using factor analysis and multiple regression. An examination of the research objective revealed two technological factors, which are a combination of adoption cost and complexity (as the first factor) as well as the combination of relative advantage and compatibility (as the second factor) that influence green practices adoption in every manufacturing company. Also, five organizational factors (regulatory support, organizational support, quality of human resources, environmental factors and customer pressure) influence green practices adoption with eigenvalues greater than 1 and Cronbach's alpha greater than 0.700 . Test of hypotheses revealed that compatibility $(\beta=0.191, \mathrm{t}=2.033 ; \mathrm{P}<.05)$, organizational support $(\beta=-0.303, \mathrm{t}=-3.595 ; \mathrm{P}<.05)$, environmental factors $(\beta=-0.219, \mathrm{t}=-3.199 ; \mathrm{P}<.05)$ significantly independently predicted infusion of green practices while, adoption cost $(\beta=-0.087, \mathrm{t}=.909 ; \mathrm{P}>.05)$, complexity $(\beta=0.022, \mathrm{t}=.264 ; \mathrm{P}<.05)$, relative advantage $(\beta=0.072, t=808 ; \mathrm{P}>.05)$, quality of human resource $(\beta=0.125, \mathrm{t}=1.364 ; \mathrm{P}>.05)$, government support $(\beta=-.031, \mathrm{t}=-464 ; \mathrm{P}>.05)$, regulatory support $(\beta=-.118, \mathrm{t}=-1.562 \mathrm{P}>.05)$ and customer pressure $(\beta=-.119, \mathrm{t}=-1.557 ; \mathrm{P}>.05)$ had no significant independent prediction on infusion of green practices. The findings of the study were discussed within the existing literature and recommendations were provided for policy intervention.
\end{abstract}

Keywords: Environment, Green Practices, Sustainable Manufacturing, Development

\section{Introduction}

In the past few years especially since the declaration of the World Earth Summit in Rio de Janeiro in 1992, corporate organizations had been advised to join other stakeholders in the effort to revitalize the human environment and to achieve sustainable development. In today's sustainable development era, business organizations are also the agent of change process particularly in addressing the issue of environmental pollution, biodiversity loss, climate change as well as the scarcity of water, energy and mineral resources that are hampering on human and social development across the globe-by becoming more environmentally friendly in their dealings [1-3]. In this context, business organizations are not only accepted for their socio-economic contributions and their positions in the market but also recognized by their performance in promoting sustainable green systems, practices, as well as community development actions $[4,5]$. To fulfil the anticipated socio-economic and environmental obligations by business companies especially manufacturing firms-who are widely known as key actors of socio-economic development as well as greenhouse emissions- eco-friendly practices must be adopted and infused into their modus operandi. While there had been impressive adoption and 
infusion of green practices in developed and in many developing countries (like China, Taiwan, Malaysia, Singapore, Thailand and South Africa), extant literature [6-8] showed that a majority of the manufacturing companies operating in Nigeria are yet to implement green practices in their business operations; hence generating negative externalities with impacts on human and social development. Against this backdrop, this study set out to investigate factors influencing green practices adoption and infusion by manufacturing companies in Ogun State, Nigeria.

Green practices are eco-supported innovations, alternatives and principles designed by ecopreneurs and used by organizations to tackle the challenge of environmental degradation and resource depletion. They also include proenvironmental behaviours such as purchasing ecofriendly products, producing renewable goods, recycling, using pollution abatement equipment and efficient waste management techniques to reduce the rate of carbon emissions, resource misuse, waste generation and other environmental hazards associated with socio-economic activities $[2,9]$. Green practices equally envelop strategic green improvement systems like green supply chain, green management practices, great safety techniques, green lean six sigma, green balanced scorecard strategy, green technology and innovation $[10,11,12-14]$. The benefits of green practices adoption and infusion by manufacturing companies are numerous. Green Jr., et. al., [3], Lin \& Ho, [15] and Bergmiller \& McCright, [11] cited lessening the environmental impact of socioeconomic activities, high business impacts, increase efficiency, reduce costs, improve customer response time, greater profitability and improve environmental quality. Green practices also enhance competitive advantage and quality of employees' well-being [9].

Evidence gathered from literature as noted by Conding et.al, [9] revealed that there are five different dimensions of green practices namely; internal environmental management (the practice of increasing environmental performance as a strategic organizational imperative for senior and mid-level managers); technology integration (include tacit knowledge sharing, technical training, and modified systems that are used to monitor green practices and outcomes); logistics management (integrated life-cycle management of green practices flowing from the supplier, through to manufacturer, customer, and closing loop with reverse logistics); customer focus (cooperation with customers that promote the design and development of customer's friendly environmental practices); and supplier focus (cooperation with suppliers to develop products and services that are environmentally acceptable). Each of these dimensions contributes significantly to the reception and implementation of green practices in business organizations. It is important to note here that green practices implementation has two phases; the adoption phase that deals with the process by which green practices are embraced by business organizations and the infusion phase that borders on the range at which green practices are used by business organizations. Also, some authors have observed that there are influential factors that affect the adoption and infusion of green practices in contemporary business organizations [16, 17]. These factors vary in their influential capabilities and they are context and product-specific. It is based on this reality that the study investigates the factors influencing the adoption and infusion of green practices by manufacturing companies in Ogun State, Nigeria. The manufacturing firms examined in the study were selected based on the nature of products as per the National Standard Industrial Classification (NSIC) or International Standard Industrial Classification (ISIC) codes [18]. An in-depth understanding of these factors will guide in the designing of intervention programs and policies aim at achieving success in green practices implementation in Nigeria and beyond.

\section{Theoretical Exposition}

The theoretical perspectives adopted for the present study are derived from the Diffusion of Innovation Theory (DOI), TechnologyOrganisation-Environment (TOE) framework, and Behaviour Change Theory (BCT). The considerations for deploying these theories rest on the acuity that DOI and TOE framework and BCT give a valuable theoretical basis to explicate the 
nuances surrounding green practices adoption and infusion.

\subsection{Diffusion of Innovation Theory}

The Diffusion of Innovation (DOI) perspective has its origin in the theoretical production of Rogers [19] who sought to explain how, why, and to what degree an innovation will be shared and adopted by other individuals and organisations across regions or geographical boundaries. According to Rogers, innovation is an idea, practice, or object that is perceived as a novel by an individual, group of individuals or other social units of adoption. The decision to adopt an innovation, according to Rogers, is the process through which an individual (or other decisionmaking units) passes from first knowledge of an innovation to forming an attitude toward the innovation, to decide to adopt or reject, to the implementation of the idea, and confirmation of this decision. Based on this theoretical postulation, Rogers suggests that there are five different categories of innovation adopters which include the innovator (are the first group of people to adopt, use or practice innovation because they are the originators of such innovation); the early adopter (are the second quickest category of innovation adopters); the early majority (are the category of adopters who accept an innovation after a varying degree of time); the late majority (are the category of people who decides to adopt an innovation after the average members of the society have adopted the innovation) and the laggards (are the category of adopters who adopt an innovation after another category of adopters have adopted the innovation). However, the diffusion of innovation theory seems not to have recognized the influence of organizational and environmental factors in the innovation-decision process which led to the incorporation of the technology-organizationenvironmental framework.

\subsection{Technology-Organization-Environment Framework}

The Technology-Organization-Environment framework adopted in the study was offered by Tornatzky and Fleischer [20]. The TOE framework holds that organizational adoption of innovation is instigated and perpetuated by a set of technological, organizational and environmental factors. These factors could either encourage or discourage the adoption and infusion of green practices by manufacturing companies in Nigeria. According to Tornatzky and Fleischer [20], it can be affirmed that organizational culture, cooperate decision-makers, government support, external pressure, external information source, competitors, legal environment, employees and environmental uncertainty as well as access to resources supplied by others significantly determine the adoption and infusion of green practices by manufacturing companies in Nigeria. Unfortunately, TOE silenced the influence of behavioural factors in the process of implementing green practices in its theoretical supposition. This observation drives us to employ a behavioural change theory in the study.

\subsection{Behavioural Change Theory (BCT)}

This theory focuses on the environmental, personal and behavioural characteristics that help to understand why human behaviour changes at given circumstances, time and space [21]. According to the basic tenet of BCT, human behaviour (individual or group) is built on personal attitude (beliefs and values about the outcome of the behaviour) and subjective norms (beliefs about what other people think the person should do or general social pressure). Also, the theory postulates that there are driving forces that facilitate changes in human behaviour as well as inhibiting forces that hinder changes in human behaviour. Consequently, Hruschka [22] noted that inhibiting forces for technology adoption (e.g. green practices) might include, for instance, lack of subsidies, corruption, poor environmental regulation, lack of machinery, and limited knowledge. On the other hand, driving forces encompass, for example, financial assistance, technical advice, training, provision of inputs, and linkage with market outlets. On the whole, BCT proposes five stages (rejection, acceptance, behaviour modification, adoption and implementation) which behavioural change process must undergo. This means that green practices adoption and infusion by manufacturing companies is an outcome of the completion of the behavioural 
change process. In other words, the adoption and infusion of green practices by manufacturing companies must have transcended above the inhibiting forces that might work against its implementation by the manufacturing firms in Nigeria.

\section{Methodology}

\subsection{Research Design}

This study adopted a descriptive and crosssectional design in which the questionnaire was employed in collecting data from the respondents on the subject matter.

\subsection{Participants}

The participants for the study comprised of 500 employees of ten manufacturing companies in four Local Government Areas in Ogun State, Nigeria. The participants were employees in the following Departments (Procurement and Logistics, Sales and Marketing, Production and Quality Control, Environmental Management, Human Resource and Customer's Relations). The reason for the consideration of these departments' lies in the fact that employees who work in those Departments are expected to have in-depth knowledge of the subject matter and would be able to provide useful information for the study. Also, the participants for the study cut across different occupational cadres (junior, intermediary, supervisory and senior management cadre) which were selected through a multi-stage sampling technique. The distribution of the sample size is presented in Table 1.

Table 1: Distribution of Sample Size by Each Manufacturing Company

\begin{tabular}{cclcc}
\hline Manufacturing Firms & Size of the Firm & LGAs & Samples & Percentage (\%) \\
\hline A & Large & Ado-Odo/Ota (Agbara) & 66 & 13.2 \\
B & Large & Ado-Odo/Ota & 21 & 4.3 \\
C & Large & Ado-Odo/Ota & 42 & 8.3 \\
D & Large & Ado-Odo/Ota & 34 & 6.7 \\
E & Large & Ado-Odo/Ota & 18 & 3.5 \\
F & Large & Ewekoro & 60 & 12.2 \\
G & Medium & Ewekoro & 18 & 3.5 \\
H & Medium & Ewekoro & 9 & 1.8 \\
I & Large & Egbado-North (Ibese) & 152 & 30.5 \\
J & Large & Obafemi-Owode (Magboro) & 80 & 16.0 \\
\hline
\end{tabular}

Source: Field Survey, 2017

The table 1 above shows the information about the number of selected manufacturing firms, size of the firm, local governmental areas, as well as sample and percentage distribution by each manufacturing firm participating in the study. Based on this information in the table, we can deduce that each of the selected manufacturing company is represented by alphabet in ascending order due to the request for anonymity and confidentiality of the company's name by the respondents. Also, the majority of the selected companies are large-scale manufacturing firms. This is largely due to the report that most of the large-scale manufacturing firms often embrace the use of green practices in their operations than the medium-and-small-scale firms. Similarly, we can infer from the table 1 that sample size and percentage distribution vary from one company to another. This is due to the variation in the total number of staff in each selected manufacturing firms. Hence, the sample size is proportionate to the study population.

\subsection{Instrumentation}

A semi-structured questionnaire was employed in this study. The questionnaire contained 31 items on a 6-point Likert type scale. The items were adapted with some modifications from the Adoption Scale developed by Bishop [23] using the Sigma scoring method. The scale consisted of 31 items with responses ranging from 1-Not All 2-To a small extent 3-To a moderate 
extent 4- To a considerable extent 5-To a great extent 6- Not applicable. The questionnaire has a Cronbach alpha value of 0.896 (technological influence) and 0.875 (organizational influence) as the internal consistency and revalidation reliability respectively. Besides, experts in psychometrics who confirmed the validity of the instrument subjected the questionnaire to construct and content validity scrutiny.

\subsection{Inclusion and Exclusion Criteria}

The selection procedure was directed by the inclusion and exclusion criteria to ensure that qualified individuals and targeted manufacturing companies are considered for partaking in the study. The utilization of inclusion and exclusion criteria in a research study has been recognized as part of the main principles of conducting an empirical study [24]. The inclusion and exclusion criteria for the study are displayed in Table 2.

Table 2: Inclusion and Exclusion Criteria

\begin{tabular}{ll}
\hline Inclusion Criteria & Exclusion Criteria \\
\hline Senior and junior employees of selected & Individuals who are not the staff of the selected \\
manufacturing companies; those who are working & manufacturing companies or those who are not working \\
within selected departments in the manufacturing in the selected departments or those who are not \\
companies; and they are knowledgeable about the knowledgeable about the research problem at hand \\
subject matter.
\end{tabular}

Source: Field Survey, 2017

Table 2 presents the inclusion and exclusion criteria employed in the study. The information in table 2 shows that not all the staff in the selected manufacturing companies participated in the study and thus, it is only those who meet up with the set inclusion criteria are allowed to partake in the study while other members of staff are excluded.

\subsection{Procedure for Data Collection}

The respondents for the study were served questionnaires with the help of two trained research assistants to elicit information on the subject at hand. The retrieved questionnaires were scored and the data obtained from them were analysed to achieve the purpose of the study. Overall, it took the researcher and assistants two months to administer and collect the distributed questionnaires. This is due to the bureaucratic nature of corporate organizations and the need to observe the ethical considerations associated with the study. Three hundred and twenty-one (321) copies of questionnaires were duly filled and returned, giving a return rate of $64.2 \%$.

\subsection{Data Analysis}

The data gathered from respondents were analysed through descriptive statistics and factor analysis to identify the factors influencing the adoption of green practices by manufacturing companies in Ogun State, Nigeria.

\subsection{Ethical Issues in Data Collection}

Ethical standards, which incorporate deliberate investment, obscurity, and secrecy, were carefully seen over the span of this examination. As a matter of first importance, endorsement was looked for from each leader of the office under investigation. While the assent of the planned respondents was additionally acquired before the instrument was dispersed to them. Additionally, every respondent was made to realize that they are allowed to retreat from the investigation anytime. The respondents were informed about the normal results or advantages of the examination so their interest in the investigation can be determined. The data acquired from the respondents was utilized for scholastic reason and the personalities of the respondents were kept anonymous.

\section{Results and Discussion}

\subsection{Socio-Demographic Variables of the Respondents}

The gender distribution of showed that male respondents $238(74.1 \%)$ are outnumbered the female respondents $83(25.9 \%)$. This suggests that 
a majority of the employees in the selected manufacturing firms are males and this represents the patriarchy nature of Nigerian society where male gender controls the public sphere of society. Also, the results revealed that the majority of the respondents $300(93.5 \%)$ are within the economic active population while $21(6.5 \%)$ are age 44 years and above. Moreover, the educational distribution of respondents showed that the entire respondent had a formal education with at least the primary school leaving qualification and the distribution on year spent by respondents revealed that they have spent minimum of a year in the organization. However, the result didn't show the number of the individuals who have recently worked in another manufacturing company before joining the current company in any case, the outcome uncovers that the greater part of the respondents had been working in the chose associations for over 5 years which likewise demonstrates that they are satisfactorily qualified by the consideration criteria set by the investigators to participate in the study. Thusly, we can construe that the data accumulated from them depends on their comprehension of the social and real world factors that surround them.

\subsection{Factors Influencing Green Practices Adoption in Manufacturing Companies in Nigeria}

The study employed principal component analysis (PCA) and factor analysis (FA), a multivariate technique used to reduce a large number of variables or objects to a set of scores underlying factors. The 31 items in the instrument were decomposed into a few factors with related factor scores that explained the variations in the observed variables. Factor analysis was used to determine the number of factors influencing green practices adoption. The FA was undertaken in five key steps; preliminary analysis, assessment of the suitability of data for factor analysis (pretest), factor extraction, factor rotation and factor interpretation. Preliminary EFA led to the generation of the following statistical outputs: descriptive statistics, correlation matrix, commonalities, KMO measure of sampling adequacy and Bartlett's Test of sphericity, and total variance explained. The descriptive statistics in Table 3 shows the mean, standard deviation and the number of respondents (n) in the combined data Table 3.

Table 3. Descriptive Statistics of the Entire Data Set

\begin{tabular}{|c|c|c|c|c|}
\hline No. & Study Variables & $\mathrm{N}$ & Mean & $\begin{array}{l}\text { Std. } \\
\text { deviation }\end{array}$ \\
\hline 1. & We spend a lot of money to evaluate green practices & 321 & 4.24 & .991 \\
\hline 2 & The cost involved in using green practices is expensive & 321 & 4.13 & .802 \\
\hline 3 & We spend a lot of time to evaluate the green practices & 321 & 4.02 & .950 \\
\hline 4 & Using green practices needs much experience & 321 & 4.10 & .823 \\
\hline 5 & Learning green practices is difficult & 321 & 3.88 & 671 \\
\hline 6 & Sharing knowledge of green practices is difficult & 319 & 4.10 & .808 \\
\hline 7 & The green practices can provide better environmental performance & 321 & 4.23 & .917 \\
\hline 8 & The green practices can provide higher economic benefits & 321 & 4.12 & .782 \\
\hline 9 & The green practices can enhance our company's reputation & 321 & 4.24 & .842 \\
\hline 10 & $\begin{array}{l}\text { The green practices are compatible with our existing manufacturing } \\
\text { operations }\end{array}$ & 321 & 4.32 & .749 \\
\hline 11 & The green practices are consistent with our company's value & 321 & 4.12 & .780 \\
\hline 12 & $\begin{array}{l}\text { Integrating the green practices with the company's existing system is } \\
\text { easy }\end{array}$ & 321 & 4.10 & .798 \\
\hline 13 & $\begin{array}{l}\text { Employees are capable of using new technologies to solve problems } \\
\text { easily }\end{array}$ & 321 & 4.22 & .993 \\
\hline 14 & $\begin{array}{l}\text { Employees are capable of providing new ideas for our company } \\
\text { through the use of green innovation }\end{array}$ & 321 & 3.90 & .875 \\
\hline 15 & Employees are capable of learning new technology easily & 321 & 4.17 & .813 \\
\hline
\end{tabular}


$\overline{16}$ Employees are capable of sharing knowledge

17 Top management encourages employees to learn green knowledge

18 Our company provides rewards for employee's green behaviour

19 Top management can help employees dealing with environmental issues

20 Our company provides resources for employees to learn green knowledge

21 Environmental uncertainty

22 Predicting competitors behaviour is difficult

$\underline{23}$ Customers' preferences vary frequently

$\underline{24}$ The advance in green manufacturing is quickly

25 The government provides financial support for adopting green practices

26 Government helps train manpower with green manufacturing skills

27 The government provides technical assistance for adopting green practices

28 The government sets environmental regulations for manufacturing operations

29 Industrial associations require us to conform to environmental regulations as contained in the ISO-14001 certification

30

Our customers require us to improve environmental performance

Caring for the environment is an important consideration for our customers

Source: Field Survey, 2017

The mean column in Table 3 shows that "The green practices are compatible with our existing manufacturing operations" had the highest mean $=4.32$, followed by "Government helps train manpower with green manufacturing skills" with a mean $=4.26$, "The government provides technical assistance for adopting green practices $=4.25$, "The green practices can enhance our company's reputation" with a mean $=4.24$ and "The green practices can provide better environmental performance" with a mean $=4.23$. From the descriptive statistics, these were the variables with the greatest influence on the adoption and infusion of green practices among manufacturing companies because they had the highest mean scores. The combined data set was split into two groups namely; technological characteristics and organizational characteristics that are described in Table 4.

The inter-item correlation matrix in Table 4 shows that none of the items has a negative value, which implies that all the items are measuring the same underlying characteristics. This is because the presence of negative value would have indicated that in the process of questionnaire design, some of the questions were reversed, but that is not to say that they will have reversed scored in the transcription stage [25].

\subsection{Technological Characteristics Influencing Green Practices Adoption and Infusion in Manufacturing Firms in Ogun State, Nigeria}

The commonalities associated with the combined dataset are displayed in Table 5 shows that the least commonality value was 0.353 associated with the variable, "integrating the green practices with the company's existing system is easy" and the variable with the highest commonality was, "the cost involve in using green practices is expensive" $(0.691)$. This indicated that the variables fitted well with each other as Table 5 explained. 
Table 4: Inter-item Correlation Matrix

\begin{tabular}{|c|c|c|c|c|c|c|c|c|c|c|}
\hline Variable & $\begin{array}{l}\text { Adoptio } \\
\mathrm{n} \text { cost }\end{array}$ & $\begin{array}{l}\text { Compl } \\
\text { exity }\end{array}$ & $\begin{array}{l}\text { Relative } \\
\text { advanta } \\
\text { ge }\end{array}$ & $\begin{array}{l}\text { Compati } \\
\text { bility }\end{array}$ & $\begin{array}{l}\text { Quality of } \\
\text { human } \\
\text { resources }\end{array}$ & $\begin{array}{l}\text { Organizati } \\
\text { onal } \\
\text { support }\end{array}$ & $\begin{array}{l}\text { Environ } \\
\text { mental } \\
\text { uncertai } \\
\text { nty } \\
\end{array}$ & $\begin{array}{l}\text { Gover } \\
\text { nment } \\
\text { suppor } \\
\mathrm{t}\end{array}$ & $\begin{array}{l}\text { Regul } \\
\text { atory } \\
\text { suppor } \\
\mathrm{t}\end{array}$ & $\begin{array}{l}\text { Consum } \\
\text { er } \\
\text { pressure }\end{array}$ \\
\hline Adoption cost & 1.000 & & & & & & & & & \\
\hline Complexity & .842 & 1.000 & & & & & & & & \\
\hline $\begin{array}{l}\text { Relative } \\
\text { advantage }\end{array}$ & .721 & .832 & 1.000 & & & & & & & \\
\hline Compatibility & .807 & .609 & .981 & 1.000 & & & & & & \\
\hline $\begin{array}{l}\text { Quality of } \\
\text { human } \\
\text { resources }\end{array}$ & .651 & .724 & .684 & .658 & 1.000 & & & & & \\
\hline $\begin{array}{l}\text { Organizationa } \\
1 \text { support }\end{array}$ & .813 & .817 & .671 & .822 & .705 & 1.000 & & & & \\
\hline $\begin{array}{l}\text { Environmenta } \\
1 \text { Uncertainty }\end{array}$ & .753 & .683 & .639 & .758 & .811 & .914 & 1.000 & & & \\
\hline $\begin{array}{l}\text { Government } \\
\text { support }\end{array}$ & .841 & .816 & .533 & .699 & .809 & .613 & .872 & 1.000 & & \\
\hline $\begin{array}{l}\text { Regulatory } \\
\text { support }\end{array}$ & .719 & .735 & .694 & .773 & .909 & .451 & .912 & .896 & 1.000 & \\
\hline $\begin{array}{l}\text { Customer } \\
\text { pressure }\end{array}$ & .817 & .741 & .789 & .798 & .818 & .706 & .893 & .806 & .719 & 1.000 \\
\hline
\end{tabular}

The data was also subjected to two requirements of factor analysis, Kaiser-MeyerOlkin (KMO) measure of sampling adequacy and Bartlett's test of sphericity. The KMO test statistics of 0.852 was established as shown in Table 6 . Kaiser (1974) recommended accepting KMO values greater than 0.5 as acceptable. Nonetheless, Hutcheson \& Sofroniu [26] posited that KMO values between 0.5 and 0.7 are mediocre, values between 0.7 and 0.8 are good, values between 0.8 and 0.9 are great and values above 0.9 are superb, hence the value 0.852 was adequate in this study. Bartlett's test was used to test the strength of the relationship between variables. The Bartlett's test of sphericity result shows that $\mathrm{p}$-value $=0.000$ was significant and less than the threshold of 0.05 as Table 6 depicted.

Table 5: Communalities

\begin{tabular}{|c|c|c|}
\hline Variable & Initial & Extraction \\
\hline We spend a lot of money to evaluate GP & 1.000 & 0.646 \\
\hline The cost involved in using GP is expensive & 1.000 & 0.691 \\
\hline We spend a lot of time to evaluate the GP & 1.000 & 0.600 \\
\hline Using the GP needs many experiences & 1.000 & 0.626 \\
\hline Learning the GP is difficult & 1.000 & 0.671 \\
\hline Sharing knowledge of the GP is difficult & 1.000 & 0.443 \\
\hline The GP can provide better environmental performance & 1.000 & 0.563 \\
\hline The GP can provide higher economic benefits & 1.000 & 0.681 \\
\hline The GP can enhance our company's reputation & 1.000 & 0.678 \\
\hline
\end{tabular}


The GP practices are compatible with our existing manufacturing operations

Source: Field Survey, 2017

Table 6: KMO and Bartlett's Test

\begin{tabular}{lll}
\hline Kaiser-Meyer-Olkin Measure of Sampling Adequacy & 0.852 \\
\hline Barlett's Test of Sphericity & Approx. Chi-Square & 1869.292 \\
& Df & 66 \\
& Sig. & 0.000 \\
\hline
\end{tabular}

Furthermore, the initial solution was determined using the PCA method. This was a two-stage method comprising an unrotated solution and a rotated solution. The PCA was preferred because it allowed for the reduction of the data set to a manageable size while retaining as much of the original information. The unrotated solution in Table 7 shows a total of 12 components out of which 2 components explained 58.993 per cent of the variations leaving 41.007 per cent of the variations to be explained by the other 10 components as Table 7 explained.

Table 7: Total Variance Explained by the Combined Data

\begin{tabular}{|ccccccc|}
\hline \multirow{2}{*}{ Component } & \multicolumn{2}{l}{ Initial Eigenvalues } & \multicolumn{2}{l|}{ Extraction Sums of Squared Loadings } \\
\cline { 2 - 7 } & \multicolumn{1}{l}{ Total } & $\begin{array}{l}\text { Percentage of } \\
\text { Variance }\end{array}$ & $\begin{array}{l}\text { Cumulative } \\
\text { percentage }\end{array}$ & Total & $\begin{array}{l}\text { Percentage } \\
\text { Variance }\end{array}$ & $\begin{array}{l}\text { Cumulative } \\
\text { percentage }\end{array}$ \\
\hline 1 & 5.526 & 46.049 & 46.049 & 5.526 & 46.049 & 46.049 \\
2 & 1.553 & 12.945 & 58.993 & 1.553 & 12.945 & 58.933 \\
3 & 0.833 & 6.945 & 65.938 & & & \\
4 & 0.733 & 6.105 & 72.043 & & & \\
5 & 0.674 & 5.615 & 77.658 & & & \\
6 & 0.635 & 5.295 & 82.953 & & & \\
7 & 0.510 & 4.253 & 87.206 & & & \\
8 & 0.428 & 3.563 & 90.769 & & & \\
9 & 0.370 & 3.087 & 93.856 & & & \\
10 & 0.300 & 2.501 & 96.357 & & & \\
11 & 0.247 & 2.058 & 98.415 & & & \\
12 & 0.190 & 1.585 & 100.000 & & & \\
\hline
\end{tabular}

Source: Primary Data, 2017

Using Kaiser's criterion, the study sought variables with eigenvalues greater than or equal to one. The first two components had eigenvalues greater than or equal to one (5.526 and 1.553 respectively) and accounted for 58.993 per cent of the variations, with component 1 accounting for 46.049 per cent of the variations, and component 2 explained 12.553. Therefore based on the total variance explained analysis, a maximum of two components could be extracted from the combined data set. Moreover, the rotated component matrix of the combined data in Table 8, led to the extraction of two components with 12 items loading on component one and component two as Table 8 described. 
Variable

Component (Factor)

1

2

Adoption cost and Relative advantage and Complexity Compatibility

Learning green practice is difficult

0.811

0.113

0.809

0.191

The cost involved in using green practices is expensive

0.780

0.194

We spend a lot of time to evaluate the green practices

0.702

0.329

Using green practices needs many experiences

0.698

0.372

Sharing knowledge of green practices is difficult

0.652

0.132

The green practices are consistent with our company

0.052

0.806

value

The green practices can enhance our company's

0.206

0.797

reputation

The green practices provide higher economic benefits

0.432

0.703

The green practices are compatible with our existing

0.214

0.656 manufacturing operations

The green practice can provide better environmental performance

Integrating the green practices with the company's existing system is easy

Source: Field Survey, 2017

The results in Table 8 above reveal that two components which comprised of the combination of adoption cost and complexity (as component one), as well as relative advantage and compatibility (as component two), are the technological factors influencing green practices adoption in all the manufacturing companies under study.

\subsection{Organizational \\ Characteristics Influencing Green Practices Adoption and}

\section{Infusion in Manufacturing Firms in Ogun State, Nigeria}

Factor analysis of the organizational characteristics that influenced green practices adoption in all the manufacturing companies revealed KMO statistics $=.752$ and Barlett's test of sphericity resulted in $\mathrm{p}$-value $=0.000$, which was significant and meant that variables in the organizational characteristics data were correlated and good for factor analysis as Table 9 explained.

Table 9: KMO and Bartlett's Test

\begin{tabular}{lll}
\hline \multicolumn{2}{l}{ Kaiser-Meyer-Olkin Measure of Sampling Adequacy } & 0.752 \\
\hline Barlett's Test of Sphericity & Approx. Chi-Square & 3501.914 \\
& Df & 171 \\
& Sig. & 0.000 \\
\hline
\end{tabular}

Analysis of the data set using the correlation matrix revealed that the data did not have singularity problems and that the variables were related to each other and hence suitable for factor analysis as Table 10 described. 


\begin{tabular}{lcc}
\hline Variable & Initial & Extraction \\
\hline Employees are capable of using new technologies to solve problems easily & 1.000 & 0.655 \\
Employees are capable of providing new ideas for our company & 1.000 & 0.624 \\
Employees are capable of learning new technology easily & 1.000 & 0.624 \\
Employees are capable of sharing knowledge & 1.000 & 0.506 \\
Top management encourages employees to learn green knowledge & 1.000 & 0.641 \\
Our company provides rewards for employees' green behaviour & 1.000 & 0.706 \\
Top management can help employees dealing with environmental issues & 1.000 & 0.621 \\
Our company provides resources for employees to learn green knowledge & 1.000 & 0.673 \\
Environmental uncertainty & 1.000 & 0.740 \\
Predicting competitors behaviour is difficult & 1.000 & 0.648 \\
Customer preferences vary frequently & 1.000 & 0.765 \\
The advance in green manufacturing is quickly & 1.000 & 0.716 \\
The government provides financial support for adopting green practices & 1.000 & 0.790 \\
Government helps train manpower with green manufacturing skills & 1.000 & 0.766 \\
The government provides technical assistance for adopting green practices & 1.000 & 0.667 \\
The government sets environmental regulations for manufacturing operations & 1.000 & 0.676 \\
Industrial associations require us to conform to environmental regulations as & 1.000 & 0.827 \\
contained in the ISO 14001 certification & & \\
Our customers require us to improve environmental performance & 1.000 & 0.889 \\
Caring for the environment is an important consideration for our customers & 1.000 & 0.795 \\
\hline
\end{tabular}

Source: Field Survey, 2017

The commonalities result also show that the variables fitted well with each other. Using EFA, factors were extracted from the combined data set in two steps, unrotated solution and rotated solution analysis. The initial output of the EFA process was the total variance explained results in Table 11.

Table 11: Total Variance Explained in Every Manufacturing Company

\begin{tabular}{|c|c|c|c|c|c|c|}
\hline \multirow{2}{*}{ Component } & \multicolumn{3}{|c|}{ Initial Eigenvalues } & \multicolumn{3}{|c|}{ Extraction Sums of Squared Loadings } \\
\hline & Total & $\begin{array}{l}\text { Percentage } \\
\text { of Variance }\end{array}$ & $\begin{array}{l}\text { Cumulative } \\
\text { percentage }\end{array}$ & Total & $\begin{array}{l}\text { Percentage } \\
\text { of Variance }\end{array}$ & $\begin{array}{l}\text { Cumulative } \\
\text { percentage }\end{array}$ \\
\hline 1 & 5.855 & 30.815 & 30.815 & 5.855 & 30.815 & 30.815 \\
\hline 2 & 2.743 & 14.436 & 45.250 & 2.743 & 14.436 & 45.250 \\
\hline 3 & 2.157 & 11.351 & 56.601 & 2.157 & 11.351 & 56.601 \\
\hline 4 & 1.351 & 7.108 & 63.709 & 1.351 & 7.108 & 63.709 \\
\hline 5 & 1.224 & 6.440 & 70.149 & 1.224 & 6.440 & 70.149 \\
\hline 6 & .985 & 5.186 & 75.335 & & & \\
\hline 7 & .766 & 4.032 & 79.367 & & & \\
\hline 8 & .566 & 2.977 & 82.344 & & & \\
\hline 9 & .529 & 2.783 & 85.127 & & & \\
\hline 10 & .469 & 2.470 & 87.597 & & & \\
\hline 11 & .426 & 2.241 & 89.838 & & & \\
\hline 12 & .394 & 2.075 & 91.913 & & & \\
\hline 13 & .354 & 1.863 & 93.776 & & & \\
\hline 14 & .306 & 1.612 & 95.389 & & & \\
\hline
\end{tabular}




$\begin{array}{lccc}15 & .263 & 1.385 & 96.774 \\ 16 & .227 & 1.194 & 97.968 \\ 17 & .144 & .758 & 98.726 \\ 18 & .134 & .704 & 99.430 \\ 19 & .108 & .570 & 100.000\end{array}$

Source: Field Survey, 2017

Using the PCA method, 5 components were extracted and they explained 70.149 per cent of the cumulative variations. The remaining 29.851 per cent of the variations were explained by the remaining 57 components. Component one explained 30.815 per cent of the variations, component two explained 14.436 per cent of the variations, component three explained 11.351 per cent of the variations, and component four explained 7.108 while component five explained 6.440 per cent of the variations. The total initial eigenvalues column shows that the first 5 components had eigenvalues greater than or equal to $\geq 1$ also confirmed that the 5 components were the most important. The rotated component matrix for organizational characteristics in all the manufacturing companies was presented in Table 12.

Table 12. Rotated Component Matrix for Organizational Characteristics (in every manufacturing companies) in Ogun State, Nigeria

\begin{tabular}{|c|c|c|c|c|c|}
\hline \multirow[b]{2}{*}{ Variable } & \multicolumn{5}{|c|}{ Component } \\
\hline & $\begin{array}{l}\text { Regulatory } \\
\text { Support }\end{array}$ & $\begin{array}{l}\text { Organizational } \\
\text { Support }\end{array}$ & $\begin{array}{l}\text { Quality of } \\
\text { human } \\
\text { resources }\end{array}$ & $\begin{array}{l}\text { Envionmental } \\
\text { factors }\end{array}$ & $\begin{array}{l}\text { Customer } \\
\text { pressure }\end{array}$ \\
\hline $\begin{array}{l}\text { Industrial associations require us to } \\
\text { conform to environmental } \\
\text { regulations as contained in the ISO } \\
14001 \text { certification }\end{array}$ & .827 & -.206 & .154 & -.072 & .269 \\
\hline $\begin{array}{lll}\text { Government } & \text { sets } & \text { environmental } \\
\text { regulations } & \text { for } & \text { manufacturing } \\
\text { operations } & & \end{array}$ & .755 & -.123 & .136 & .114 & .244 \\
\hline $\begin{array}{l}\text { Top management encourages } \\
\text { employees to learn green knowledge }\end{array}$ & .634 & .465 & .117 & .092 & .000 \\
\hline Environmental uncertainty & .618 & .246 & -.071 & .535 & -.075 \\
\hline $\begin{array}{l}\text { Employees are capable of using new } \\
\text { technology easily }\end{array}$ & .581 & .232 & .463 & .220 & .038 \\
\hline $\begin{array}{l}\text { Employees are capable of sharing } \\
\text { knowledge }\end{array}$ & .483 & .409 & .184 & -.154 & .219 \\
\hline 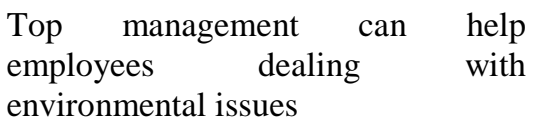 & .075 & .778 & .049 & .007 & -.089 \\
\hline $\begin{array}{l}\text { Our company provides resources for } \\
\text { employees to learn green knowledge }\end{array}$ & -.225 & .723 & .219 & .132 & .183 \\
\hline $\begin{array}{l}\text { Our company provides rewards for } \\
\text { employees' green behaviour }\end{array}$ & .112 & .666 & -.112 & .261 & .412 \\
\hline $\begin{array}{l}\text { Employees are capable of learning } \\
\text { new technology easily }\end{array}$ & .333 & .495 & .172 & .350 & .341 \\
\hline $\begin{array}{l}\text { Employees are capable of providing } \\
\text { new ideas for our company }\end{array}$ & .387 & .415 & .306 & .352 & .290 \\
\hline The government provides financial & .004 & .168 & .866 & -.042 & -.101 \\
\hline
\end{tabular}


support for adopting green practices

Government helps train manpower with green manufacturing skills

The government provides technical assistance for adopting green practices

Customers' preferences vary -.027

frequently

Predicting competitors behaviour is .322

difficult

The advance in green manufacturing $\quad-.290$

is quickly

Our customers require us to improve .150

environmental performance

Caring for the environment is an

important consideration for our

customers

Source: Field Survey, 2017

The results in Table 12 above reveal that five components namely; regulatory support, organizational support, quality of human resources, environmental factors and customer pressure are the organizational characteristics influencing green practices adoption in all the manufacturing companies.

\subsection{Hypothesis Testing}

The research hypotheses formulated for this study were;

H01: Technological factors (adoption cost, compatibility, complexity and relative advantage) of green practices adoption does not influence green practices infusion in manufacturing companies

H02: Organizational factors (organizational support, quality of human resources, regulatory support, environmental factors, government support and customer pressure) of green practices adoption has no influence on green practices infusion in manufacturing companies

In testing the above hypotheses, the study employed multiple regression analysis to examine the influence of the predictors and dependent variables as Table 13 depicted.

Table 13. Summary of Multiple Regression Analysis showing Technological and Organizational Factors as Predictors of Green Practices Infusion in Manufacturing Companies

\begin{tabular}{|c|c|c|c|c|c|c|c|c|}
\hline Predictors & $\beta$ & $\mathrm{T}$ & $P$ & $\mathrm{R}$ & $\mathrm{R}^{2}$ & Adjusted $\mathrm{R}^{2}$ & $\mathrm{~F}$ & $P$ \\
\hline Adoption cost & -.087 & .909 & $>.05$ & \multirow{10}{*}{.463} & \multirow{10}{*}{.214} & \multirow{10}{*}{.184} & \multirow{10}{*}{7.069} & \multirow{10}{*}{$<.05$} \\
\hline Complexity & .022 & .264 & $>.05$ & & & & & \\
\hline Relative advantage & .072 & .808 & $>.05$ & & & & & \\
\hline Compatibility & .191 & 2.033 & $<.05$ & & & & & \\
\hline Quality of human resources & .125 & 1.364 & $>.05$ & & & & & \\
\hline Organizational support & -.303 & -3.595 & $<.05$ & & & & & \\
\hline Environmental factors & -.219 & -3.199 & $<.05$ & & & & & \\
\hline Government support & -.031 & -.464 & $>.05$ & & & & & \\
\hline Regulatory support & -.118 & -1.562 & $>.05$ & & & & & \\
\hline Customer pressure & -.119 & -1.557 & $>.05$ & & & & & \\
\hline
\end{tabular}

Source: Field Survey, 2017 
Table 13 showed that technological factors (adoption cost, complexity, relative advantage, and compatibility) and organizational factors (quality of human resources, organizational support, environmental factors customer pressure), government support, regulatory support, are significantly and jointly predicted infusion of green practices by the manufacturing firms $\{\mathrm{F}(10,256)=$ 7.069; $\mathrm{P}<.05\}, \mathrm{R}^{2}=.184$. The Table 13 also reveals that compatibility $(\beta=0.191, \mathrm{t}=2.033 ; \mathrm{P}<.05)$, organizational support $(\beta=-0.303, \mathrm{t}=-3.595 ; \mathrm{P}<$ $.05)$, environmental factors $(\beta=-0.219, \mathrm{t}=-3.199 ; \mathrm{P}$ $<$.05) significantly independently predicted infusion of green practices by the manufacturing firms. Meanwhile, adoption cost $(\beta=-0.087, \mathrm{t}=.909 ; \mathrm{P}$ $>.05)$, complexity $(\beta=0.022, \mathrm{t}=.264 ; \mathrm{P}<.05)$, relative advantage $(\beta=0.072, \mathrm{t}=808 ; \mathrm{P}>.05)$, quality of human resource $(\beta=0.125, \mathrm{t}=1.364 ; \mathrm{P}>$ $.05)$, government support $(\beta=-.031, \mathrm{t}=-464 ; \mathrm{P}>$ $.05)$, regulatory support $(\beta=-.118, \mathrm{t}=-1.562 \mathrm{P}>$ $.05)$ and customer pressure $(\beta=-.119, \mathrm{t}=-1.557 ; \mathrm{P}>$ $.05)$ had no significant independent prediction on infusion of green practices by the manufacturing firms.

\subsection{Discussion of Findings}

The first research objective was to investigate the factors influencing green practices adoption in manufacturing firms in Nigeria. To achieve this objective, the combined manufacturing data set was split into two classifications namely; technological characteristics and organizational characteristics. Based on the technological characteristics, the study established that there were two factors, which are a combination of adoption cost and complexity (as the first technological factor) as well as the combination of relative advantage and compatibility (as the second technological factor) that influence green practices adoption in every manufacturing company in Ogun State, Nigeria. Table 8 provides a summary of these factors in their order of magnitude. This finding corroborates with Weng \& Lin [16] who reported that complexity, compatibility and benefits of green innovation are factors that affect the adoption of green behaviour by small and medium enterprises (SMEs) in China. The finding upholds Del Rio Gonzalez [17] (2005) who observed that economic and financial advantages are essential technological characteristics that determine the adoption of clean technologies in the Spanish pulp and paper industry. However, the finding of this study also differs from Weng \& Lin [16] and Del Rio Gonzalez [17] in terms of the combination of two technological characteristics as a determinant factor that influence green practices adoption in every manufacturing company in Ogun State, Nigeria.

In terms of the organizational characteristics that influence green practices in manufacturing firms in Ogun State, Nigeria, the study established there were five organizational factors (regulatory support, organizational support, quality of human resources, environmental factors and customer pressure) that influence green practices adoption in every manufacturing companies in Ogun State, Nigeria. Table 12 provides a summary of these factors in their order of magnitude. The findings corroborate Cronstam and Grönberg [27] who reported that factors like customer pressure, supplier relationship, management engagement and environmental management systems influence the implementation of green management practices among Swedish SMEs in Logistics. In a similar vein, the findings of the study uphold the findings of Abidin, Abdullahi \& Osman [28] who established that the factors influencing the adoption of clean production strategies among food and beverage firms in Peninsular Malaysia include technology characteristics, technology performances and communication networks. The findings tally with the work of Sidek \& Backhouse [29] who submitted that legislation factors, customer requirement, business opportunities and company responsibility are the factors that influence the adoption of environmental sustainability practices into operation by metal and fabrication SMEs in the United Kingdom and Malaysia. Also, the findings support the outcomes of the research conducted by Nyakundi [30] who established that external factors that influence the adoption of green manufacturing in food processing firms in Kenya include government regulation and incentives, customers demand, stakeholder pressures, and competitive advantage.

\section{Conclusion and Recommendations}

The study concluded that determinant factors (technological and organizational) have a significant influence on green practices adoption and infusion in 
manufacturing companies in Nigeria. Four technological characteristics (adoption cost, compatibility, complexity and relative advantage) and five organizational characteristics (regulatory support, organizational support, quality of human resources, environmental factors as well as customer pressure) that lead to green practices adoption by manufacturing firms in Nigeria. The findings of the study revealed that while determinant factors have a different impact on green practices adoption, they are still connected and influence the other's effect. The study established that the dominant technological factors that influence green practices adoption in manufacturing companies in Nigeria are: adoption cost, compatibility, complexity and relative advantage. These factors can act as motivators but they can also prove to be obstacles depending on a company's internal capabilities and knowledge. Moreover, the study showed that the dominant organizational factors that influence green practices adoption in manufacturing companies in Nigeria are: government support and quality of human resources. Concerning the extent to which determinant factors influence green practices infusion, the study established that adoption cost, compatibility, complexity, organizational support, customer pressure, regulatory support as well as environmental factors have much influence on green practices infusion among manufacturing firms in Ogun State, Nigeria.

\section{Acknowledgements}

We acknowledged the valuable information and views about the research problem given by the staff of the Ministry of Environment in Ogun State, Nigeria. Also, we extend our gratitude to the officials of the Ogun State Environmental Protection Agency for their opinions about the steps for improving the quality of environment and green practices implementation.

\section{References}

[1]. Alliyu, N. and Solaja, M.O (2016) The Political Economy of Nigeria's Green Practices Adoption in the Era of Sustainable Development Goals (SDGs). Social Studies 10(2): 99-114.
[2] Ho, Y. H, Lin, C.Y, and Tsai, J.S. (2014) An Empirical Study on Organizational Infusion of Green Practices in Chinese Logistics Companies. Journal of Economic and Social Studies 4(2): 159-189.

[3] Green, Jr. K. W., Zelbst, P. J., Meacham, J., and Bhadauria, V. S. (2012) Green supply chain management practices: Impact on performance. Supply Chain Management-An International Journal 17 (3): 1-44.

[4] Karabasevic, D., Paunkovic, J., and Stanujkic, D. (2016) Ranking of Companies According to the Indicators of Corporate Social Responsibility Based on SWARA and ARAS Methods. Serbian Journal of Management 11(1): 43-53

[5] Solaja, M.O and Adetola, O.B (2018) Situating Green Practices within the context of the Sustainable Development Agenda. Equity and Development 30: 195-220.

[6] Eruola A. O., Ufoegbune G. C., Eruola A. O., Awomeso J. A., Adeofun C. O., Idowu O.A. \& Abhulimen, S. I.(2011) An assessment of the effect of industrial pollution on Ibese River, Lagos, Nigeria. African Journal of Environmental Science and Technology 5(8): 608-615.

[7] Aribigbola, A., Fatusin, A.F., and Fagbohunka, A (2012) Assessment of Health and Environmental Challenges of Cement Factory on Ewekoro Community Residents, Ogun State, Nigeria. American Journal of Human Ecology 1(2): 51-57

[8] Bada, B. S., Olatunde, K. A., and Oluwajana A. (2013) Air quality assessment in the vicinity of Cement company. International Research Journal of Natural Sciences 1(2): 34-42.

[9] Conding, J., Zubir, M.F.A., Hashim, A.S., \& SriLanang, A. N. (2012) A Proposed of Green Practices and Green Innovation Model in Malaysia Automotive Industry. Environmental Management and Sustainable Development 1(2): $90-100$

[10] Shishi, K. P., Sashidharan, R. N., Nazry, Y and Jeannot, A. K. (2015) An Integrated Model of the Likelihood and Extent of Adoption of Green Practices in Small and Medium-Sized Logistics Firms. American Journal of Economics, 5(2): 251-258. 
[11] Bergmiller, G. G. and McCright, P. R. (2009). Parallel models for lean and green operations. Proceedings of the Industrial Engineering Research Conference, Zero Waste Operations Research and Consulting, USA.

[12] Dallas, N. (2008). Green Business Basics: 24 Lessons for Meeting the Challenges of global warming. New York: McGraw-Hill.

[13] Henriques, I., and Sadorsky P. (2007) Environmental technical and administrative innovations in the Canadian Manufacturing Industry. Bus. Strategy. Environ. 16 (2): 119132.

[14] Rottenburg and Zyglidopolos (2003) Determinants of Environmental Innovation Adoption in the Printing Industry A research monograph of the printer industry service at RIT.

[15] Lin, C. Y., \& Ho, Y. H. (2011) Determinants of green practice adoption for logistics companies in China. Journal of Business Ethics, 98(1): 6783.

[16] Weng, H.M. \& Lin, Y. C (2011). Determinants of green innovation adoption for small and medium-sized enterprises (SMEs). African Journal of Business Management, 5(22): 91549163

[17] Del Rio Gonzalez, P. (2005) Analysing the Factors Influencing Clean Technology Adoption: A Study of the Spanish Pulp and Paper Industry', Business Strategy and the Environment 14(1): 20-37.

[18] National Bureau of Statistics (2014) Nigerian Manufacturing Sector Summary Report: 20102012. Retrieved online from https://www.proshareng.com/admin/upload /reports/ Manufacturing sector 20102012.pdf on $12^{\text {th }}$ August 2018

[19] Rogers, E.M. (2003). Diffusion of innovations (5th ed.). New York: Free Press

[20] Tornatzky, L. and Fleischer, M. (1990) The process of technology innovation, Lexington, MA, Lexington Books.

[20] Bandura, A. (1986) Social foundations of thought and action: A social cognitive theory. Englewood Cliffs, NJ: Prentice-Hall.
[21] Hruschka, E. (1994) Psychological basis of the consultation process. In: H. Albrecht (Ed.): Insight as Agent of Action, Margraf Verlag, Weikersheim, 5-24.

[22] Bishop, O.O. (2017) A framework for measuring adoption of innovation: improved cassava varieties in Delta State Nigeria. Extension Farming Systems Journal 9 (1): 171177

[23] Bhandari U, Kanojia R, Pillai K.K. (2002). Effect of ethanolic extract of Embelia ribes on dyslipidemia in diabetic rats. Int J Exp Diab Res. 3:159-162.

[24] George, D. \& Mallery, P. (2003). SPSS for Windows step by step: A simple guide and reference. 11.0 update (4th ed.). Boston, MA: Allyn \& Bacon.

[25] Hutcheson G., \& Sofroniou N. (1999) The multivariate social scientist: Introductory statistics using generalized linear models. London: Sage Publication. '

[26] Cronstam, O. and Grönberg, J. (2017) Factors Influencing the Implementation of Green Management: A Qualitative Study regarding Swedish SMEs in Logistics. Bachelor's Thesis in Business Administration. Jonkoping University, International Business School. https://www.divaportal.org/smash/get/diva2:1116776/FULLTEX T01.pdf.

[27]Abidin, R., Abdulahi, C, S \& Osman, W. N (2010) Clean Production Strategies Adoption: A Survey on Food and Beverage Manufacturing Sector. Communications of the IBIMA.

[28] Sidek, A.A and Backhouse, C.J., (2014) Environmental sustainability issues in Malaysian metal and fabrication SMEs: a comparative analysis from a case study perspective. Proceedings of the 2014 International Conference on Industrial Engineering and Operations Management, Bali, Indonesia, 7th-9th January 2014, pp.1653-1662.

[29] Nyakundi, D.O.(2013).Management Perception of Bankassurance as Risk Mitigation Strategy at Equity Bank. Unpublished MBA Project, University of Nairobi. 